\title{
Succession of Insect Pest Complex and their Natural Enemies in Pigeonpea [Cajanus Cajan (L) Millsp.]
}

\author{
Ajay Kumar Bijewar ${ }^{*}$, S.B. Das and A.K. Saxena
}

Department of Entomology, College of Agriculture, JNKVV, Jabalpur (M.P.), India

*Corresponding author

\begin{tabular}{l} 
K e y w o r d s \\
Pigeonpea [Cajanus \\
$\begin{array}{l}\text { Cajan (L) Millsp.], } \\
\text { Coccinella } \\
\text { septempunctata } \\
\text { (Linn.) }\end{array}$ \\
\hline Article Info \\
$\begin{array}{l}\text { Accepted: } \\
\text { 07 June } 2019 \\
\text { Available Online: } \\
\text { 10 July } 2019\end{array}$ \\
\hline
\end{tabular}

A B S T R A C T
An experiment was conducted during kharif season 2015-2016 at experimental field, Department of Entomology, Live Stock Farm, Adhartal, Jawaharlal Nehru Krishi Vishwa Vidyalaya, Jabalpur (M.P.), to observe the "Succession of Insect Pest Complex and Their Natural Enemies in Pigeonpea [Cajanus Cajan (L) Millsp.]". Result revealed that 17 species of insects (13 pest and 4 natural enemies) were observed in pigeonpea i.e. Jassids Empoasca fabae Harris, Cow bug Otinotus oneratus W., Pod bug Clavigralla gibbosa Spinola, Riptortus sp., Red cotton bug Dysdercus koengi Fabricius, Green stink bug Nezara viridula Linn, Grasshopper Cyrtacanthacris sp. (L.), Red pumpkin beetle Aulacophora foveicollis (Lucas), Thrips Megalurothrips usitatus Baganll, Pod fly Melanagromyza obtusa (Malloch), Leaf webber Grapholita critica (Meyr), Gram pod borer Helicoverpa armigera (Hub.), Tur plume moth Exelastis atomosa (W.), Spider, Hognan lenta, Lady bird beetle, Coccinella septempunctata (Linn.), Green lace wing, Chrysoperla sp. and Wasp Cotessia (=Apanteles) sp.

\section{Introduction}

Pigeonpea (Cajanus cajan (L) Millsp.) is an important multi-use shrub legume of the tropics and subtropics. The crop originated from India and moved to Africa about 4,000 years ago. Unlike other grain legumes, pigeonpea production is concentrated in developing countries, particularly in a few South and Southeast Asia and Eastern and Southern African countries. It is the preferred pulse crop in dryland areas where it is intercropped or grown in mixed cropping systems with cereals or other short duration annuals without significantly reducing the yield (Joshi et al., 2001). Its grain is of high nutritional value with high protein content that ranges from $21 \%$ to over $25 \%$ making it very valuable for improving food security and nutrition for many poor families who cannot afford dairy and meat-based diet (Kimani, 2001). 
Pigeonpea has a wide range of products, including the dried seed, pods and immature seeds used as green vegetables, leaves and stems used for fodder and the dry stems as fuel. It also improves soil fertility through nitrogen fixation as well as from the leaf fall and recycling of the nutrients (Snapp et al., 2002). It is an important pulse crop that performs well in poor soils and regions where moisture availability is unreliable or inadequate.

Pigeonpea a tropical grain legume, mainly grown in India and ranks second in area and production and contributes about $90 \%$ of the world's pulse production. In India during 2014 pigeonpea was cultivated in an area of 3.88 million ha and production of about 3.29 million tonnes, with a productivity of $849 \mathrm{~kg}$ /ha (DES, 2014).

In the country, the crop is extensively grown in Uttar Pradesh, Madhya Pradesh, Maharashtra, Karnataka, Andhra Pradesh and Gujarat. Uttar Pradesh has a unique distinction of contributing about $20 \%$ production in the country followed by Madhya Pradesh (Sahoo and Senapati, 2000). In Madhya Pradesh, during 2014 pigeonpea was cultivated in an area of about 0.49 million hectare with production of 0.46 million tonnes and 955 $\mathrm{kg} /$ ha productivity (DES, 2014). In Jabalpur, during 2013-14 it was cultivated in an area of 10,930 hectare with a total production of 9,700 tonnes and $886 \mathrm{~kg} / \mathrm{ha}$ productivity (www.mpkrishi.org 2013-14).

Though India is the largest producer of pigeonpea, the productivity has always been a great concern, and the productivity of pigeonpea has not increased considerably during last decade. The damage caused by insect pests is one of the major reasons of low productivity. They key pests include pod borer complex viz. gram pod borer (Helicoverpa armigera Hubner), plume moth (Exelastis atomosa Walsingham), pod fly (Melanagromyza obtusa Malloch) and pod bug (Clavigralla gibbosa Spinola) which cause considerable losses in grain yield ranging from 30 to $100 \%$ (Satpute and Barkhade, 2012).

Pod infesting insect pests recorded at Jabalpur are gram pod borer (H. armigera Hubner), pod bug (C. gibbosa Spinola), pod fly (M. obtusa Malloch) and plume moth (E. atomosa Walsingham). Out of the four pests, $M$. obtusa has established as the most important pest on the basis of pod and grain damage which range from about 55 to 85 and 29 to 63 per cent, respectively (Landge, 2009). Pod fly now has become an important biotic constraint in increasing the production and productivity under subsistence farming conditions, irrespective of agro ecological zones. The survey of Marathwada region of Maharashtra during 2007-08 revealed that the damage by pod fly ranged from 25.5 to $36 \%$ (Anonymous 2008). The estimates of avoidable losses due to pod borer complex, mainly pod fly and $H$. armigera were 43.5 and $30.2 \%$, respectively (Anonymous 2012). The present study was done to observe the "Succession of Insect Pest Complex and Their Natural Enemies in Pigeonpea [Cajanus Cajan (L) Millsp.].

\section{Materials and Methods}

The present investigation entitled, "Succession of Insect Pest Complex and Their Natural Enemies in Pigeonpea [Cajanus Cajan (L) Millsp.]" was carried out in the experimental field, Department of Entomology, Live Stock Farm, Adhartal, Jawaharlal Nehru Krishi Vishwa Vidyalaya, Jabalpur (M.P.) during kharif season 2015-2016.

\section{Methodology of observations}

Observations on different insects were recorded on 25 randomly selected plants twice 
in a standard week. It was initiated after germination and was taken upto the maturity of the crop. Observations of jassids (nymph + adult) were recorded on six leaves per plant viz., each from 2 upper, middle and lower leaves per plant. Observations on leaf webber, spider, green stink bug (nymph + adult), pod bug (nymph + adult), pod borer larvae and plume moth(larvae + pupae) were recorded on per plant basis, while pod fly maggot were recorded on randomly selected 25 pods per 5 plants. Sweep nets were used for population monitoring of weak and active insect fliers and the methodology was adopted as proposed by Abd-Elsamed et al., (2011). Meteorological data were collected and correlation studies were carried out with the various insect population.

\section{Results and Discussion}

Result revealed that 17 insects were observed in pigeonpea i.e. Jassids Empoasca fabae Harris, Cow bug Otinotus oneratus W., Pod bug Clavigralla gibbosa Spinola, Riptortus sp., Red cotton bug Dysdercus koengi Fabricius, Green stink bug Nezara viridula Linn, Grasshopper Cyrtacanthacris sp. (L.), Red pumpkin beetle Aulacophora foveicollis (Lucas), Thrips Megalurothrips usitatus Baganll, Pod fly Melanagromyza obtusa (Malloch), Leaf webber Grapholita critica (Meyr), Gram pod borer Helicoverpa armigera (Hub.) and Tur plume moth Exelastis atomosa (W.) Spider, Hognan lenta, Lady bird beetle, Coccinella septempunctata (Linn.), Green lace wing, Chrysoperla sp. and Wasp Cotessia (= Apanteles) sp (Table 1).

\section{Leaf webber, Grapholita critica Meyr (Lepidoptera: Tortricidae)}

First appearance of the leaf webber was observed when the crop age was about 8 days i.e., vegetative stage. The pest was present on the crop during the vegetative stage and remained available upto the fourth week of November i.e. reproductive stage of the crop (115 days). Similar findings have been reported by Kumar and Nath (2003), Ambhure (2012), Pandey (2013), Pawar et al., (2014) and Shinde and Patel (2014). They also reported that leaf webber infested pigeonpea during the vegetative and remained available upto the reproductive stage of the crop.

\section{Jassid, Empoasca fabae Harris (Hemiptera: Cicadellidae)}

First appearance of jassid was observed when the crop age was about 53 days i.e. vegetative stage. It is evident that the pest was present on the crop during the vegetative stage and remained available upto the second week of December i.e. maturity stage of the crop (110 days).Similar findings have been reported by Kumar and Nath (2003), Balikai and Yelshetty (2008), Mahalle (2008), Landge (2009), Pandey (2013), Pawar et al., (2014) and Shinde and Patel (2014). They also reported that jassids infested pigeonpea during the vegetative stage and remained available upto the reproductive stage of the crop. However, in the present study incidence of the jassids was observed in the seedling stage and it was available till the maturity stage of the crop.

\section{Cow bug, Otinotus oneratus W. (Hemiptera: Membracidae)}

First appearance of cow bug was observed when the crop age was about 53 days i.e. vegetative stage. It is evident that the pest was present on the crop during the vegetative stage and remained available upto the second week of November i.e. reproductive stage of the crop (77days). The present findings confirm the findings of Mahalle (2008), Ambhure (2012) and Pandey (2013). They also reported that cow bug infested pigeonpea during the vegetative stage and remained available upto the reproductive stage of the crop. 


\section{Grasshopper Cyrtacanthacris sp. (L.)}

First appearance of the grasshopper was observed when the crop age was about 64 days i.e. vegetative stage. It is evident that the pest was present on the crop during the vegetative stage and remained available upto the third week of November i.e. reproductive stage of the crop (80 days). However, no information about grasshopper on pigeonpea seems to be available in the literature.

\section{Pod bug, Clavigralla gibbosa Spinola (Hemiptera: Coreidae)}

First appearance of the pod bug was observed when the crop age was about 74 days i.e. vegetative stage. It is evident that the pest was present on the crop during the vegetative stage and remained available upto the first week of January i.e. maturity stage of the crop (116 days). The present findings are in accordance with the findings of Minja et al., (1999), Joshi and Shrivastava (2006), Mahalle (2008), Balikai and Yelshetty (2008), Rana et al., (2008), Landge (2009), Srilaxmi and Paul (2010), Ambhure (2012), Pandey (2013), Pawar et al., (2014), Shinde and Patel (2014), Vikram (2015) and Pandey et al., (2016). They also reported that pod bug infest pigeonpea from vegetative stage and remained available upto the maturity stage of the crop.

\section{Riptortus, Riptortus sp. (Hemiptera: Coreidae)}

First appearance of riptortus pod bug was observed when the crop age was about 74 days i.e. vegetative stage. It is evident that the pest was present on the crop during the vegetative stage and remained available upto the first week of January i.e. maturity stage of the crop (112 days). The present findings are in accordance with the findings of Joshi and Shrivastava (2006), Mahalle (2008), Balikai and Yelshetty (2008), Landge (2009) and
Ambhure (2012). They also reported that riptortus pod bug infest pigeonpea from vegetative stage and remained available upto the maturity stage of the crop.

\section{Red cotton bug, Dysdercus koengi Fabricius (Hemiptera: Pyrrhocoridae)}

First appearance of the red cotton bug was observed when the crop age was about 74 days i.e. vegetative stage. It is evident that the pest was present on the crop during the vegetative stage and remained available upto the third week of November i.e. reproductive stage of the crop (63 days). The present findings are in conformity with the findings of Pandey (2013). He also reported that red cotton bug infest pigeonpea during the vegetative stage and remained available upto the reproductive stage of the crop.

\section{Red pumpkin beetle, Aulacophora foveicollis (Lucas) (Coleoptera: Chrysomelidae)}

First appearance of the red pumpkin beetle was observed when the crop age was about 74 days i.e. vegetative stage. It is evident that the pest was present on the crop during the vegetative stage and remained available upto the second week of October i.e. reproductive stage of the crop (28 days).

The present finding confirms the findings of Pandey (2013) and Pawar et al., (2014). They also reported that red pumpkin beetle infest pigeonpea from vegetative stage and remained available upto the reproductive stage of the crop.

Green stink bug, Nezara viridula Linn (Hemiptera: Pentatomidae)

First appearance of the green stink bug was observed when the crop age was about 88 days i.e. vegetative stage. 
Table.1 Succession of insect complex on pigeonpea at Jabalpur during kharif 2015-16

\begin{tabular}{|c|c|c|c|c|c|c|}
\hline \multirow{3}{*}{$\begin{array}{l}\text { S W (Date of } \\
\text { Observation) }\end{array}$} & \multicolumn{4}{|c|}{ Insects Name } & \multirow{3}{*}{$\begin{array}{l}\text { Crop } \\
\text { age } \\
\text { (days) }\end{array}$} & \multirow{3}{*}{$\begin{array}{c}\text { Cro } \\
\text { p } \\
\text { Stag } \\
\text { e }\end{array}$} \\
\hline & \multicolumn{2}{|r|}{ Name } & \multirow[t]{2}{*}{ Order } & \multirow[t]{2}{*}{ Family } & & \\
\hline & Common & Scientific & & & & \\
\hline \multirow{8}{*}{$\begin{array}{l}31^{\text {st }} \text { to } 35^{\text {th }} \\
(30 / 7 / 2015 \text { to } \\
2 / 9 / 2015)\end{array}$} & Leaf webber & Grapholita critica (Meyr) & Lepidoptera & Tortricidae & \multirow{8}{*}{$\begin{array}{l}30- \\
60\end{array}$} & \multirow[t]{8}{*}{ VS } \\
\hline & Jassid & Empoasca fabae (Harris) & Hemiptera & Cicadellidae & & \\
\hline & Cow bug & Otinotus oneratus W. & Hemiptera & Membracidae & & \\
\hline & Grasshopper & Cyrtacanthacris sp. & Orthoptera & Acrididae & & \\
\hline & Spider & Telamonia dimediata & Araneae & Salticidae & & \\
\hline & $\begin{array}{l}\text { Lady bird } \\
\text { beetle }\end{array}$ & $\begin{array}{l}\text { Coccinella septempunctata } \\
\text { Linn. }\end{array}$ & Coleoptera & Coccinellidae & & \\
\hline & $\begin{array}{l}\text { Green lace } \\
\text { wing }\end{array}$ & Chrysoperla sp. & Neuroptera & Chrysopidae & & \\
\hline & Wasp & Cotessia (Apanteles)sp. & Hymenoptera & Braconidae & & \\
\hline \multirow{13}{*}{$\begin{array}{l}36^{\text {th }} \text { to39 } \\
(3 / 9 / 2015 \text { to } \\
30 / 9 / 2015)\end{array}$} & Leaf webber & Grapholita critica (Meyr) & Lepidoptera & Tortricidae & \multirow{13}{*}{$\begin{array}{l}61- \\
90\end{array}$} & \multirow[t]{13}{*}{ VS } \\
\hline & Jassid & Empoasca fabae (Harris) & Hemiptera & Cicadellidae & & \\
\hline & Cow bug & Otinotus oneratus W. & Hemiptera & Membracidae & & \\
\hline & Grasshopper & Cyrtacanthacris sp. & Orthoptera & Acrididae & & \\
\hline & Pod bug & Clavigralla gibbosa Spinola & Hemiptera & Coreidae & & \\
\hline & $\begin{array}{l}\text { Red pumpkin } \\
\text { beetle }\end{array}$ & $\begin{array}{l}\text { Aulacophora foveicollis } \\
\text { (Lucas) }\end{array}$ & Coleoptera & Chrysomelidae & & \\
\hline & Riptortus & Riptortus sp. & Hemiptera & Coreidae & & \\
\hline & Red cotton bug & $\begin{array}{l}\text { Dysdercus koengii } \\
\text { (Fabricius) }\end{array}$ & Hemiptera & Pyrrhocoreidae & & \\
\hline & $\begin{array}{l}\text { Green stink } \\
\text { bug }\end{array}$ & Nezara viridula Linn. & Hemiptera & Pentatomidae & & \\
\hline & Spider & Telamonia dimediata & Araneae & Salticidae & & \\
\hline & $\begin{array}{l}\text { Lady bird } \\
\text { beetle }\end{array}$ & $\begin{array}{l}\text { Coccinella septempunctata } \\
\text { Linn. }\end{array}$ & Coleoptera & Coccinellidae & & \\
\hline & $\begin{array}{l}\text { Green lace } \\
\text { wing }\end{array}$ & Chrysoperla sp. & Neuroptera & Chrysopidae & & \\
\hline & Wasp & Cotessia (Apanteles)sp. & Hymenoptera & Braconidae & & \\
\hline \multirow{18}{*}{$\begin{array}{l}40^{\text {th }} \text { to } 44^{\text {th }} \\
(1 / 10 / 2015 \text { to } \\
4 / 11 / 2015)\end{array}$} & Leaf webber & Grapholita critica (Meyr) & Lepidoptera & Tortricidae & \multirow{17}{*}{$\begin{array}{l}91- \\
120\end{array}$} & \multirow[t]{17}{*}{ VS } \\
\hline & Jassid & Empoasca fabae (Harris) & Hemiptera & Cicadellidae & & \\
\hline & Cow bug & Otinotus oneratus W. & Hemiptera & Membracidae & & \\
\hline & Grasshopper & Cyrtacanthacris sp. & Orthoptera & Acrididae & & \\
\hline & Pod bug & Clavigralla gibbosa Spinola & Hemiptera & Coreidae & & \\
\hline & $\begin{array}{l}\text { Red pumpkin } \\
\text { beetle }\end{array}$ & $\begin{array}{l}\text { Aulacophora foveicollis } \\
\text { (Lucas) }\end{array}$ & Coleoptera & Chrysomelidae & & \\
\hline & Riptortus & Riptortus sp. & Hemiptera & Coreidae & & \\
\hline & Red cotton bug & Dysdercus koengii Fabricius & Hemiptera & Pyrrhocoreidae & & \\
\hline & $\begin{array}{l}\text { Green stink } \\
\text { bug }\end{array}$ & Nezara viridula Linn. & Hemiptera & Pentatomidae & & \\
\hline & Pod fly & $\begin{array}{l}\text { Melanagromyza obtusa } \\
\text { Malloch }\end{array}$ & Diptera & Agromyzidae & & \\
\hline & $\begin{array}{l}\text { Gram pod } \\
\text { borer }\end{array}$ & Helicoverpa armigera Hub. & Lepidoptera & Noctuidae & & \\
\hline & Thrips & $\begin{array}{l}\text { Megalurothrips usitatus } \\
\text { Bagnall }\end{array}$ & Thysanoptera & Thripidae & & \\
\hline & Plume moth & $\begin{array}{l}\text { Exelastis atomosa } \\
\text { Walsingham }\end{array}$ & Lepidoptera & Pterophoridae & & \\
\hline & Spider & Telamonia dimediata & Araneae & Salticidae & & \\
\hline & $\begin{array}{l}\text { Lady bird } \\
\text { beetle }\end{array}$ & $\begin{array}{l}\text { Coccinella septempunctata } \\
\text { Linn. }\end{array}$ & Coleoptera & Coccinellidae & & \\
\hline & $\begin{array}{l}\text { Green lace } \\
\text { wing }\end{array}$ & Chrysoperla sp. & Neuroptera & Chrysopidae & & \\
\hline & Wasp & Cotessia (Apanteles)sp. & Hymenoptera & Braconidae & & \\
\hline & Jassid & Empoasca fabae (Harris) & Hemiptera & Cicadellidae & & \\
\hline
\end{tabular}




\begin{tabular}{|c|c|c|c|c|c|c|}
\hline \multirow{3}{*}{$\begin{array}{l}\text { S W (Date of } \\
\text { observation) }\end{array}$} & \multicolumn{4}{|c|}{ Insects Name } & \multirow{3}{*}{$\begin{array}{l}\text { Crop } \\
\text { age } \\
\text { (days) }\end{array}$} & \multirow{3}{*}{$\begin{array}{l}\text { Crop } \\
\text { Stage }\end{array}$} \\
\hline & \multicolumn{2}{|r|}{ Name } & \multirow[t]{2}{*}{ Order } & \multirow[t]{2}{*}{ Family } & & \\
\hline & Common & Scientific & & & & \\
\hline \multirow{15}{*}{$\begin{array}{l}45^{\text {th }} \text { to } 48^{\text {th }} \\
(5 / 11 / 2015 \text { to } \\
2 / 12 / 2015)\end{array}$} & Cow bug & Otinotus oneratus W. & Hemiptera & Membracidae & \multirow{15}{*}{$\begin{array}{l}121- \\
150\end{array}$} & \multirow[t]{15}{*}{ RS } \\
\hline & Grasshopper & Cyrtacanthacris sp. & Orthoptera & Acrididae & & \\
\hline & Pod bug & Clavigralla gibbosa Spinola & Hemiptera & Coreidae & & \\
\hline & $\begin{array}{l}\text { Red pumpkin } \\
\text { beetle }\end{array}$ & Aulacophora foveicollis (Lucas) & Coleoptera & Chrysomelidae & & \\
\hline & Riptortus & Riptortus sp. & Hemiptera & Coreidae & & \\
\hline & Red cotton bug & Dysdercus koengii Fabricius & Hemiptera & Pyrrhocoreidae & & \\
\hline & Green stink bug & Nezara viridula Linn. & Hemiptera & Pentatomidae & & \\
\hline & Pod fly & Melanagromyza obtusa Malloch & Diptera & Agromyzidae & & \\
\hline & Gram pod borer & Helicoverpa armigera Hub. & Lepidoptera & Noctuidae & & \\
\hline & Thrips & Megalurothrips usitatus Bagnall & Thysanoptera & Thripidae & & \\
\hline & Plume moth & Exelastis atomosa Walsingham & Lepidoptera & Pterophoridae & & \\
\hline & Spider & Telamonia dimediata & Araneae & Salticidae & & \\
\hline & Lady bird beetle & Coccinella septempunctata Linn. & Coleoptera & Coccinellidae & & \\
\hline & Green lace wing & Chrysoperia sp. & Neuroptera & Chrysopidae & & \\
\hline & Wasp & Cotessia (Apanteles)sp. & Hymenoptera & Braconidae & & \\
\hline \multirow{9}{*}{$\begin{array}{c}49^{\text {th }} \text { to } 52^{\text {th }} \\
(3 / 12 / 2015 \text { to } \\
31 / 12 / 2015)\end{array}$} & Jassid & Empoasca fabae (Harris) & Hemiptera & Cicadellidae & \multirow{9}{*}{$\begin{array}{l}151- \\
180\end{array}$} & \multirow[t]{9}{*}{ MS } \\
\hline & Pod bug & Clavigralla gibbosa Spinola & Hemiptera & Coreidae & & \\
\hline & Riptortus & Riptortus sp. & Hemiptera & Coreidae & & \\
\hline & Green stink bug & Nezara viridula Linn. & Hemiptera & Pentatomidae & & \\
\hline & Pod fly & Melanagromyza obtusa Malloch & Diptera & Agromyzidae & & \\
\hline & Gram pod borer & Helicoverpa armigera Hub. & Lepidoptera & Noctuidae & & \\
\hline & Thrips & Megalurothrips usitatus Bagnall & Thysanoptera & Thripidae & & \\
\hline & Plume moth & Exelastis atomosa Walsingham & Lepidoptera & Pterophoridae & & \\
\hline & Spider & Telamonia dimediata & Araneae & Salticidae & & \\
\hline \multirow{3}{*}{$\begin{array}{c}1^{\text {st }} \text { to } 2^{\text {nd }} \\
(01 / 01 / 2016 \text { to } \\
14 / 01 / 2016)\end{array}$} & Pod fly & Melanagromyza obtusa Malloch & Diptera & Agromyzidae & \multirow[t]{3}{*}{$\begin{array}{l}181- \\
195\end{array}$} & \multirow[t]{3}{*}{ MS } \\
\hline & Thrips & Megalurothrips usitatus Bagnall & Thysanoptera & Thripidae & & \\
\hline & Spider & Telamonia dimediata & Araneae & Salticidae & & \\
\hline
\end{tabular}

VS = Vegetative stage, $\mathrm{RS}=$ Reproductive stage (Flowering / Poding stage), MS=Maturity stage

It is evident that the pest was present on the crop during the vegetative stage and remained available upto the first week of January i.e. maturity stage of the crop (98 days). The present findings confirm the findings of Landge (2009), Ambhure (2012), Pandey (2013) and Pawar et al., (2014). They also reported that green stink bug infested pigeonpea during the vegetative and remained available upto the maturity stage of the crop.

\section{Thrips, Megalurothrips usitatus Bagnall (Thysanoptera: Thripidae)}

First appearances of the thrips were observed when the crop age was about 94 days i.e. reproductive stage. It is evident that the pest was present on the crop during the reproductive stage and remained available upto the second week of January i.e. maturity stage of the crop (92 days).The present findings corroborates the findings of Kumar and Nath (2003) Balikai and Yelshetty (2008), Mahalle (2008), Landge (2009) Ambhure (2012), Pandey (2001) and Pawar et al., (2014). They also reported that thrips infested pigeonpea during the reproductive stage and remained available upto the maturity stage of the crop.

\section{Pod fly, Melanagromyza obtusa Malloch (Diptera: Agromyzidae)}

First appearance of the pod fly was observed when the crop age was about 106 days i.e. reproductive stage. It is evident that the pest was present on the crop during the reproductive stage and remained available upto the first week of January i.e. maturity stage of the crop (80 days). Similar findings have been reported by Reddy et al., (1998), Minja et al., (1999), Singh et al., (2001), 
Joshi and Shrivastava (2006), Balikai and Yelshetty (2008), Mahalle (2008), Rana et al., (2008), Landge (2009), Meena et al., (2010), Srilaxmi and Paul (2010), Rathore (2011), Ambhure (2012), Pandey (2013), Pawar et al., (2014), Shinde and Patel (2014), Vikram (2015) and Pandey et al., (2016). They also reported that pod fly infested pigeonpea during the reproductive stage and remained available upto the maturity stage of the crop.

Pod borer, Helicoverpa armigera Hub. (Lepidoptera: Noctuidae)

First appearance of the pod borer was observed when the crop age was about 109 days i.e reproductive stage. It is evident that the pest was present on the crop during the reproductive stage and remained available upto the first week of January i.e. maturity stage of the crop (77 days). The present findings confirms the findings of Reddy et al., (1998), Minja et al., (1999), Singh et al., (2001), Yelshetty et al., (2005), Joshi and Shrivastava (2006), Balikai and Yelshetty (2008), Mahalle (2008), Rana et al., (2008), Landge (2009), Srilaxmi and Paul (2010), Rathore (2011), Ambhure (2012), Pandey (2013), Pawar et al., (2014) and Shinde and Patel (2014). They also reported that pod borer infested pigeonpea during the reproductive stage and remained available upto the maturity stage of the crop.

Tur plume moth, Exelastis atomosa, Walsingham (Lepidoptera: Pterophoridae)

First appearance of pigeonpea plume moth was observed when the crop age was about 123 days i.e. reproductive stage. It is evident that the pest was present on the crop during the reproductive stage and remained available upto the second week of January i.e. maturity stage of the crop (67 days). The present findings are in agreement with those of Reddy et al., (1998), Singh (2001), Balikai and
Yelshetty (2008), Mahalle (2008), Rana et al., (2008), Landge (2009), Ambhure (2012), Pandey (2013), Pawar et al., (2014) and Shinde and Patel (2014). They also reported that plume moth infested pigeonpea during the reproductive stage and remained available upto the maturity stage of the crop.

\section{Spider, Hognan lenta (Lycoasidae:} Araneae)

First appearance of the spider was observed when the crop age was about 1 day i.e. seedling stage. It is evident that the natural enemy was present on the crop during the seedling stage and remained available upto the second week of January i.e. maturity stage of the crop (189 days). However, no information about spider on pigeonpea seems to be available in the literature.

\section{Lady bird beetle, Coccinella septempunctata (Linn.) (Coleoptera: Coccinellidae)}

First appearance of the lady bird beetle was observed when the crop age was about 53 days i.e. vegetative stage. It is evident that the natural enemy was present on the crop during the vegetative stage and remained available upto the third week of October i.e. reproductive stage of the crop (56 days). The present findings are in agreement with those of Kumar and Nath (2007), Ambhure (2012) and Pandey (2013). They also reported that lady bird beetle were observed on pigeonpea from vegetative stage and remained available upto the reproductive stage of the crop.

\section{Greenlace wing, Chrysoperla sp. (Neuroptera: Chrysopidae)}

First appearance of the greenlace wing was observed when the crop age was about 57 days i.e vegetative stage. It is evident that the natural enemy was present on the crop during 
the vegetative stage and remained available upto the second week of November i.e., reproductive stage of the crop (73days). The present findings are in conformity with the findings Kumar and Nath (2007) and Ambhure (2012). They also reported that greenlace wing were observed on pigeonpea from vegetative stage and remained available upto the reproductive stage of the crop.

\section{Wasp, Cotessia (= Apanteles) sp.} (Hymenoptera: Braconidae)

First appearance of the wasp was observed when the crop age was about 57 days i.e vegetative stage. It is evident that the natural enemy was present on the crop during the vegetative stage and remained available upto the second week of November i.e. reproductive stage of the crop (73 days). The present findings corroborate the findings of Kumar and Nath (2007), Ambhure (2012) and Pandey (2013). They also reported that wasps were observed on pigeonpea from vegetative stage and remained available upto reproductive stage of the crop.

\section{References}

Ambhure, Ganpatrao Krishna 2012. Influence of crop biodiversity on pigeonpea insect pests and their natural enemies. M. Sc. (Ag) thesis submitted to JNKVV Jabalpur.

Anonymous 2008. Annual Report of Research Work on Pulses. Marathwada Agriculture University, Parbhani. Pp. 127.

Anonymous 2012. Annual Report National Centre for Integrated Pest Management, LBS Building, Pusa Campus, New Delhi-110012; ipmnet@bol.net.in: www.ncipm.org.in. Pp. 1-113.

Balikai RA and Yelshetty S. 2008. Insect pest scenario of pigeonpea in Northern
Karnataka. Legume Reserch 31(2): 149151.

DES 2014 www.agricoop.nic.in. Agriculture Statistics at a Glance 2014. Directorate of Economics and Statistics, Department of Agriculture and Cooperation.

Joshi PK, Rao PP, Gowda CLL, Jones RB, Silim SN, Saxena KB and Kumar J. 2001. The world chickpea and pigeonpea economics: Facts, Trends and Outlook. International Crops Research Institute for the Semi-Arid Tropics, Patancheru 502 324, Andhra Pradesh, India. pp: 122.

Joshi, N. and Srivastava C.P. 2006. Yield maximization in pigeonpea through crop protection measures. Indian Farming 76(3): 4-7.

Kimani PM. 2001. Pigeonpea Breeding: Objectives, Experiences and Strategies for Eastern Africa. Eds. S.N. Silim, G. Mergeai and P.M. Kimani. In "Status and potential of pigeonpea in Eastern and Southern Africa". Proceedings of Regional Workshop, 12-15 Sep. 2000, Nairobi, Kenya. Pp. 232.

Kumar A and Nath P. 2003. Influence of weather factors on population of insect pests in pigeonpea at vegetative stage and flowering stage. Presented in the " 5 th National Symposium on Biocontrol Agents for Sustainable Management of Pests" held at G.B. Pant University of Agriculture and Technology, Pantnagar, Uttaranchal December 18-20, 2003, Pp. 137.

Kumar A and Nath P. 2007. Diversity of natural enemies of insect pest in medium- late pigeonpea. Env. and Eco. 25(2): 394-398.

Landge Kumar S. 2009. Studies on pest complex of pigeonpea Cajanus cajan (L.) and their management under late sown condition. M.Sc. 
(Ag). thesis submitted to JNKVV Jabalpur pp: 1-164.

Mahalle SC. 2008. Studies on pest complex of pigeonpea Cajanus cajan (L.) and management of pod borer complex. M.Sc. (Ag) thesis submitted to JNKVV Jabalpur.

Meena B, Srivastava CP and Sharma RP. 2010. Seasonal incidence of pod fly, Melanagromyza obtuse (Malloch) on long duration pigeonpea (Cajanus cajan L.). Annals of Plant Protection Sciences 18 (2): 394-399.

Minja EM, Ongaro, Shanower TG, Deritu JMN and Songa JM. 1999. Natural enemies associated with arthropod pests of pigeonpea in eastern Africa. International Chickpea and Pigeonpea Newsletter (6): 47-50.

Pandey AK, Keval R, Yadav A and Srivastava CP. 2016. Seasonal incidence of pod fly (Melanagromyza obtusa Malloch) and pod bug (Clavigralla gibbosa Spinola) in short duration pigeonpea. Journal of Applied and Natural Science 8(1): 28-30.

Pandey SA. 2013. Studies on pod infesting insect pest complex of pigeonpea Cajanus cajan L. (Millsp.) and their control with insecticides and biopesticides. M.Sc. (Ag) thesis submitted to JNKVV Jabalpur.

Pawar UA, Chintkuntalawar PS and Ugale TB. 2014. Studies on succession of insect pest complex and their natural enemies in pigeonpea [Cajanus cajan (L.) Millsp.]. International Journal of Plant Protection 7(2): 318-324.

Rana NS, Rana DK, Gupta A, Shukla BC and Sharma RN. 2008. Study of population dynamics of insect pests of pigeonpea. Presented in the "National Conference of Pest Management Strategies for Food Security" held at College of Agriculture, I.G.K.V. Raipur, (C.G) from May 2-3, 2008, pp: 33.
Rathore D. 2011. Studies on pest complex of pigeonpea Cajanus cajan (L.) and their management. M.Sc. (Ag) thesis submitted to JNKVV Jabalpur.

Reddy NC, Singh Y and Singh VS. 1998. Pest complex and their succession on pigeonpea variety P-33. Indian Journal of Entomology 60(4): 334-335.

Sahoo BK and Senapati B. 2000. Determination of economic thresholds for pod borer complex in pigeonpea. Indian Journal Plant Protection 28 (2): 176-179.

Satpute NS and Barkhade UP. 2012. Evaluation of rynaxypyr 20 SC against pigeonpea pod borer complex. Journal of Food Legumes 25(2): 162-163.

Shinde YA and Patel BR. 2014. Succession of insect pests and their natural enemies on pigeonpea. Insect Environment 19(4): 253-256.

Singh SP, Singh Y and Singh Yeshbir 2001. Control of pod borers on pigeonpea. Indian Journal of Entomology 63(3):356-359.

Snapp SS, Rohrbach DD, Simtowe F and Freeman HA. 2002. Sustainable soil management options for Malawi: Can small holder farmers grow more legumes? Agriculture, Ecosystems and Environment 91: 159-174.

Srilaxmi K and Paul R. 2010. Diversity of insect pests of pigeonpea (Cajanus cajan (L.) Millsp) and their succession in relation to crop phenology in Gulbarga, Karnataka. International Journal of Environmental Sciences 4(4): 273-276.

Vikram A, Keval R, Srivastava CP and Yadav A. 2015. Seasonal incidence of pod fly, Melanagromyza obtusa (Malloch) and pod bug, Clavigralla gibbosa (Spinola) in long duration pigeonpea. Journal of Experimental Zoology18: 795-797.

www.mpkrishi.org 2013-2014 Commissioner Land Records, M.P. Gwalior. 
Yelshetty S, Patil BV and Lingappa S. 2005. Role of insectivorous birds in the management of pigeonpea pod borer,
Helicoverpa armigera (Hubner). Indian Journal of Pulses Research 18(2): 226229.

\section{How to cite this article:}

Ajay Kumar Bijewar, S.B. Das and Saxena, A K. 2019. Succession of Insect Pest Complex and Their Natural Enemies in Pigeonpea [Cajanus Cajan (L) Millsp.]. Int.J.Curr.Microbiol.App.Sci. 8(07): 619-628. doi: https://doi.org/10.20546/ijcmas.2019.807.077 